\title{
ANTIFERTILITY EFFECTS OF OLDENLANDIA AFFINIS IN MALE RATS - A PRELIMINARY STUDY
}

\author{
C. R. Sewani-Rusike ${ }^{\mathrm{a}}$ and M. Gundidza ${ }^{\mathrm{b}}$.
}

\author{
${ }^{a}$ Walter Sisulu University, Faculty of Health Sciences, Department of Physiology, P.Bag X1, Mthatha

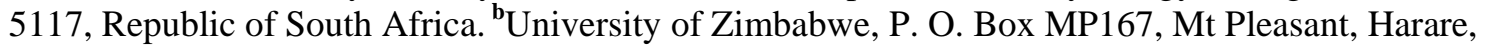 \\ Zimbabwe \\ Email: crusike@wsu.ac.za
}

\begin{abstract}
Antifertility effects of an aqueous leaf extract of Oldenlandia affinis on male rats were investigated. The extract was administered intraperitoneally in sexually mature male rats at a dose of $24 \mathrm{mg} / \mathrm{rat}(\mathrm{n}=8)$ for a total of eight injections over a 4 week period. There was a decrease in testis weights but all other accessory sex organs and vital organ weights were not affected by treatment with $O$. affinis extract. Testis histology revealed fewer spermatozoa or azoospermic seminiferous tubules in treated animals compared to controls with no change in neither tubule thickness nor Sertoli cell structure. $O$. affinis treatment caused a $17 \%$ decrease in sperm motility but there was no change in cauda epididymal sperm counts. However, serum testosterone levels decreased significantly $(\mathrm{P}<0.05)$ in the experimental group $(602.4 \pm 57 \mathrm{ng} / \mathrm{dL})$ compared to controls $(808.9 \pm 55 \mathrm{ng} / \mathrm{dL})$. These preliminary results show that the aqueous leaf extract of $O$. affinis suppresses fertility parameters in male rats.
\end{abstract}

Keywords: male contraception, aqueous extract, testosterone, sperm count, sperm motility.

\section{Introduction}

There is a growing interest in developing methods to control male fertility (Kamal et al. 2003). This will allow increased reproductive control by males while augmenting the choices available to women. This increased ability to control reproduction and space children can substantially improve women's and children's health, survival rate and economic status. Chemical agents and plant products have been described as potential male antifertility agents in the hope of developing a usable male contraceptive (Liu and Lyle. 1987; Udoh and Kehinde, 1999; Qian, 1987; Chauhan et al.2007; Singh and Singh, 2009). Thus, the search for new, safe, effective and reversible contraceptive methods for men continues to be pursued.

Oldenlandia affinis is a creeper that grows in wet vleis in the Eastern Highlands and the Southwest Lowveld of Zimbabwe. It is well known as a source of cyclic uteroactive peptides (kalata peptides) and as such, O. affinis is used as an oxytocic agent during labour in traditional medicine (Gran et al. 2000). Poor reproductive performance is reported in foraging animals where $O$. affinis grows in Zimbabwe with increased abortions and also observed smaller testes in bulls, as verbally communicated by Mr S. Mavi of the National Herbarium of Zimbabwe (Mavi, 2000). We hypothesised that in addition to causing abortion in female animals, $O$. affinis may also suppress male reproductive function thus contributing to the poor reproductive performance observed in foraging animals. The objective of this study was to investigate the effects of aqueous extract of $O$. affinis on male reproductive function, namely on reproductive organ weights, testicular histology, sperm parameters and testosterone levels. To our knowledge, the antifertility effect of $O$. affinis in male rats has not been reported.

\section{Materials and Methods \\ Plant collection and extract preparation}

The leaves of $O$. affinis used in this study were collected from the southwest lowveld area of Zimbabwe. They were authenticated using specimen vouchers at the National Botanical Gardens of Zimbabwe by Mr. Mavi, a botanist with the National Herbarium of Zimbabwe (voucher specimen GDZOF). Plant material was shade dried and pounded into a powder. 200g of plant powder was soaked in $500 \mathrm{ml}$ of distilled water overnight at room temperature, with frequent agitation using an automatic shaker with occasional manual stirring. The extract was filtered through No. 1 filter paper in a Bachman funnel, under vacuum pressure. The filtered extract was freeze dried to a powder (Edwards freeze drier) and used for animal treatments. From 800g of $O$. affinis leaf powder $100 \mathrm{~g}$ of solid matter was obtained in the aqueous extract giving a yield of $12.5 \%$.

\section{Animals and animal treatments}

This study was approved by the Ethics Committee of the Research Council, University of Zimbabwe. Sexually mature male Sprague-Dawley rats ( 250 - 300 g body weight; $262 \pm 4.2 \mathrm{~g}$ ) were purchased from the University of Zimbabwe Animal 
house and maintained on a 12 hour light and 12 hour dark cycle, and provided with food (National Foods, Harare, Zimbabawe) and water ad libitum. For animal treatments, the powder was reconstituted in $0.9 \% \mathrm{NaCl}$ solution. The treatment solution was prepared fresh for every treatment by suspending $240 \mathrm{mg}$ of O.affinis extract in $1 \mathrm{ml}$ of normal saline. The O. affinis extract and saline for controls were sterilised by expulsion through a $2.2 \mu \mathrm{m}$ Millex GV sterile filter (Millipore, Bedford, MA) attached to a 5 $\mathrm{ml}$ syringe. Rats ( $\mathrm{n}=8$ /group) were injected intraperitoneally (i.p.) with $0.1 \mathrm{ml}$ of sterile extract ( $24 \mathrm{mg} / \mathrm{animal}$ ) or $0.9 \%$ saline solution (controls) using $1 \mathrm{ml}$ syringes. Animals received two i.p. injections weekly (Mondays and Fridays) for a total of eight extract or saline solution injections over the 4-week experimental period. Three days after the final injection, animals were weighed and autopsied under ether inhalation. Blood was collected by cardiac puncture in plain tubes for serum separation and testosterone determination.

\section{Body and organ weight measurements}

Body weights at the end of the experimental period were recorded. At autopsy organs of the reproductive tract: (testes, epididymis, seminal vesicles and prostate gland) as well as vital organs (liver, heart, kidneys and spleen) were excised, cleared of adhering fat and extraneous tissue and weighed.

\section{Cauda epididymal sperm density and motility determination}

Sperm density and motility were evaluated using the method described by Linder et al. (1986). Briefly, cauda epididymis was separated and minced using a pair of small scissors, to release the sperm into $10 \mathrm{ml}$ warmed physiological saline. The sperm suspension was placed in an incubator at $37^{\circ} \mathrm{C}$ for 10 minutes prior to assessing motility. An aliquot of the sperm suspension was further diluted 5 times with warm physiological saline and then placed in Neubauer hemocytometer and motile sperm were counted under the microscope (Leica DM 1000) at 10x magnification . Five microscopic fields were observed per sample and averaged. Sperm motility was expressed as a percent of motile sperm of the total sperm counted. For sperm counts, five counts per sample were made and averaged. Sperm was expressed as sperm/ml of suspending solution.

\section{Testicular histology}

The right testes from both control and experimental groups were dissected out and fixed in formal saline. The tissues were processed for histological examination and paraffin sections were stained with hematoxylin and eosin and qualitative microscopic examination was made.

\section{Serum testosterone}

Serum concentrations of total testosterone were determined using the Coat-A-Count Total Testosterone assay kit from Diagnostic Products (DPC, Los Angeles, CA), per manufacturer's instruction for a non-extraction assay as described before (Sewani-Rusike et al., 2000). All samples were analysed in a single assay. Assay sensitivity was $0.2 \mathrm{ng} / \mathrm{ml}$ and intraassay CV was $1.2 \%(\mathrm{n}=77$ samples). Cross reactivities are: oestradiol $=0.02 \%$; $5 \alpha$-dihydrotestosterone $=3.4 \%$; and other steroids $=<1 \%$ (per DPC guidelines).

\section{Statistical analysis}

All data are expressed as mean \pm SEM. The t-test for unpaired values was used to compare control with treatment values. $\mathrm{P}<0.05$ was considered statistically significant.

\section{Results \\ Effect of $O$. affinis treatment on body and organ weights}

Treatment had no effect on body weights. As such, organ weights are reported as weight/rat. There was a significant decrease of $15 \%(\mathrm{P}<0.05)$ in testis weights in treated animals compared to controls but no effect on epididymis, seminal vesicle, and prostate weights. Spleen weights were significantly higher by $25 \%(\mathrm{P}<0.05)$ in treated animals than in controls, however, the other vital organs, namely, heart, kidney and liver weights were similar in treated and control animals (Table 1).

\section{Effect of $O$. affinis treatment on testicular histology}

In control animals, seminiferous tubules showed clear organization of cells at various stages of spermatogenesis with clear spermatozoa maturation occurring near the lumen. In treated rats, the seminiferous epithelium exhibited normal thickness as controls but the seminiferous epithelium was more compactly arranged. The tubules that contained spermatozoa within the 
lumen had very few spermatozoa. In some tubules the lumen was blocked by debris. Most of the seminiferous tubules were azoospermic. In some seminiferous tubules, the spermatozoa maturation occurred at the periphery (not near the lumen as normally the case). No changes in Leydig cell numbers and structure were observed.

Table 1: The effect of i.p administration of $O$. affinis aqueous extract (24mg/rat) on body weight, vital organ and reproductive organ weights.

\begin{tabular}{|l|l|l|}
\hline \multirow{2}{*}{ Organ } & \multicolumn{2}{|c|}{ Organ weights (grams) } \\
\cline { 2 - 3 } & Controls $(\mathrm{n}=8)$ & O. Affinis treated (n=8) \\
\hline Body & $268.5 \pm 7.3$ & $269 \pm 5.5$ \\
\hline Heart & $1.36 \pm 0.11$ & $1.34 \pm 0.04$ \\
\hline Kidneys & $2.72 \pm 0.08$ & $2.69 \pm 0.06$ \\
\hline Liver & $12.65 \pm 0.40$ & $12.84 \pm 0.33$ \\
\hline Spleen & $0.60 \pm 0.03$ & $0.70 \pm 0.03^{*}$ \\
\hline Testes & $3.31 \pm 0.13$ & $2.87 \pm 0.10^{*}$ \\
\hline Epididymis & $1.10 \pm 0.06$ & $1.13 \pm 0.06$ \\
\hline Prostate gland & $0.52 \pm 0.032$ & $0.56 \pm 0.036$ \\
\hline Seminal Vesicle & $0.45 \pm 0.021$ & $0.44 \pm 0.03$ \\
\hline
\end{tabular}

$* \mathrm{P}<0.05$, significant difference from control. Values are mean \pm S.E.M.

Effect $O$. affinis treatment on cauda epididymal sperm count, sperm motility and serum total testosterone levels

Cauda epididymal sperm count, although showing a trend to be lower in the treated group, were statistically similar to the controls. However, treatment with O.affinis resulted in a significant reduction of $15 \%$ in sperm motility $(\mathrm{P}<0.05)$ compared to controls. Testosterone levels were significantly lower $(\mathrm{P}<0.05)$ in treated animals (25\% decrease) than in controls. (Table 2)

Table 2: The effect of i.p administration of $O$. affinis aqueous leaf extract (24mg/rat) on sperm count, sperm motility and serum testosterone levels, .

\begin{tabular}{|l|l|l|}
\hline Parameter & Controls $(\mathrm{n}=8)$ & O.affinis treated $(\mathrm{n}=8)$ \\
\hline Sperm count (million per ml) & $76.4 \pm 1.82$ & $69.9 \pm 8.78$ \\
\hline Sperm motility (\%) & $83 \pm 1.89$ & $68 \pm 3.28^{*}$ \\
\hline Testosterone (ng/dL) & $808.9 \pm 55$ & $602.4 \pm 57^{*}$ \\
\hline
\end{tabular}

Values are mean \pm S.E.M. $* \mathrm{P}<0.05$, significance difference from control.

\section{Discussion}

We have shown that intraperitoneal delivery of a crude aqueous extract of $O$. affinis in mature male rats over a fourweek period results in a $25 \%$ decrease in testicular weight, with no changes in other reproductive and organ weights except spleen weights which showed a $15 \%$ increase in weight compared to controls. Seminiferous tubule organisation did not change, however it was evident histologically that there was reduced sperm production. There was a $15 \%$ decrease in sperm motility in cauda epididymis with no change in sperm density. Total serum testosterone levels were reduced by $25 \%$ after treatment with the plant extract.

The body weights and major organs of rats were not altered after treatment with $O$. affinis extract. Monitoring of body and organ weights gives information on the general well being of the animal. This is important in the interpretation of reproductive data (Claudio et al. 1999). However, splenomegaly was observed in the O. affinis treated animals. Common causes of splenomegaly include inflammation, red cell pooling, and extramedullary hematopoiesis (Spangler and Kass, 1999) . The observed splenic enlargement may have been caused by any one of these factors, possibly inflammation secondary to intraperitoneal delivery of the extract (Hardisty and Weatherall, 1974).

There was a $25 \%$ decrease in testicular weights with no change in the weights of accessory reproductive organs. Depression in spermatogenesis is usually accompanied by reduced testicular weight since the bulk of testicular weight is made up of spermatids and spermatozoa (Kenjale et al. 2008; Chauhan et al. 2007; Mann and Ludwak-Mann 1981). Histological data in our study further confirms a disturbance in spermatogenesis as evidenced by several seminiferous tubules that had very few or no spermatozoa in their lumen. Thus $O$. affinis administration resulted in reduced spermatogenesis. However, there was no significant difference in the epididymal sperm counts in O.affinis treated animals compared to controls. This could be attributed to the fact that the experiment was terminated before 60 days, equivalent to one spermatogenic cycle, thus before the testicular effects had translated to epididymal events (Mishra and Singh 2009). Normal accessory organ structure and function is maintained by circulating androgens (Mann and Ludwak-Mann, 1981; Mooradian et al. 1987). In this study there was a 25\% decrease in testosterone levels with maintenance of accessory organ weights. We don't know the actual duration of decreased testosterone in our study so the accessory organs may have not experienced testosterone deprivation long enough for weight change. However, 
the decreased sperm motility observed in the study may be an effect of altered function of the accessory organs (Hamilton 1975). Threshhold levels of required testosterone might be different for the different accessory organ functions (Chauhan et al. 2007). Leydig cell structure and number was not changed. These are the cells responsible for testosterone synthesis under the influence of leutinising hormone ( $\mathrm{LH})$. Thus the anti-androgenic effects of $O$. affinis may be via a decreased hypothalamic or anterior pituitary function or via direct effect on the testes. Others have shown a decrease in testosterone levels with decrease in accessory organ weights after 60 day treatment period in rats, equivalent to one spermatogenic cycle (Mishra and Singh 2009; Chauhan et al. 2007). Indeed, others have shown antifertility effects with no changes in testosterone levels (Sarkar et al. 2000). Testosterone plays a major role in the maintenance of spermatogenesis (Mooradian et al. 1987). In the present study, the observed reduction in spermatogenesis may thus, be attributed to testosterone deficiency.

In conclusion, $O$. affinis shows antifertility effects when administered intraperitoneally over a 4 week period in mature male rats. Further studies are essential to determine mechanism and sites of antifertility action of this plant. In addition, oral rather than intraperitoneal dosage of herbal medicines is ordinarily suitable for clinical use. Therefore further studies will examine antifertility and toxicity effects of $O$. affinis after oral delivery and over longer periods of administration.

\section{Acknowledgements}

This work was kindly supported by the Michael Gelfand Medical Research Foundation of Zimbabwe. The authors express gratitude to the Foundation and the Board of Trustees. The late Green Tendaupenyu and the late Steven Mavi are acknowledged for the technical support in this study.

\section{References}

1. Chauhan, A., Agarwal M., Kushwaha S. and Mutreja, A. (2007). Suppression of fertility in male albino rats following the administration of 50\% ethanolic extract of Aegle marmelos. Contraception 76:474-481.

2. Claudio L., Bearer C.F. and Wallinga D. (1999). Assessment of the United States Environmental Protection Agency methods for the identification of hazards to developing organisms, Part I: The Reproduction and fertility testing guidelines. Am J Ind Med 35:543-553.

3. Gran L., Sandberg F. and Sletten K. (2000). Oldenlandia affinis (R\&S) DC. A plant containing uteroactive peptides used in African traditional medicine. J Ethnopharmacol. 70(3):197-203.

4. Hamilton D.W. (1975). Structure and function of the epithelium lining the ductuli efferentes, ductus epididymis and ductus deferens in the rat. In: Hamilton DW, Green R.O. editors. Handbook of Physiology, Section 7. V. Washington (DC): American Physiological Society 259 - 301.

5. Hardisty R.M. and Weatherall D.J. (1974). Blood and Its Disorders. Blackwell Scientific Publications, Oxford, England.

6. $\quad$ Kamal, R., Gupta R.S. and Lohiya N.K. (2003). Plants for male fertility regulation. Phytother Res. 17(6): 579-590.

7. Kenjale R., Shah R., and Sathaye S. (2008). Effects of Chlorophytum borivilianum on sexual behaviour and sperm count in male rats. Phytother Res 22: $796-801$.

8. Linder R.E., Strader L.F. and McElroy W.K. (1986). Measurement of epididymal sperm motility as a test variable in the rat. Bull Environ Contam Toxicol 36:317-324.

9. Liu, G.Z. and Lyle K.C. (1987). Clinical trial of gossypol as a male contraceptive drug. Part II. Hypokalaemia study. Fertil Steril. 48(3): 462-465.

10. Mann T. and Ludwak-Mann C. (1981). In: Male reproductive function and semen. Berlin Springer-Verlag, 139 -144.

11. Mavi S. (2000) Personal communication, Harare, Zimbabwe.

12. Mishra R.K. and Singh S.K. (2009). Antispermatogenic and antifertility effects of fruits of Piper nigrum L. in mice. Indian J Exp Biol. 47(9):706-14.

13. Mooradian, A.D., Morley J.E. and Korenman S.G. (1987). Biological actions of

14. androgens. Endocrin Rev. 8:1-28.

15. Qian, S.Z. (1987). Tripterygium wilfordii, a Chinese herb effective in male fertility regulation. Contraception 36(3):33545.

16. Sarkar M., Gangopadhyay M., Basak.B., Chakrabarty K., Banerji J., Adhikary P.and Chatterjee A.(2000). The reversible antifertility effects of Piper betle Linn. on Swiss albino male mice. Contraception 62(5): 271-4.

17. Sewani -Rusike C.R., Mudambo K.S.M.T., Tendaupenyu G., Dzuda C., Tafirenyika A., and Zenda E. (2000). Effects of the Zimbabwe Defense Forces training program on body composition and reproductive hormones in male army recruits. Cent Afr J Med 46(2): 27-31.

18. Singh, A. and Singh S.K. (2009). Evaluation of antifertility potential of Brahmi in male mouse. Contraception 79:71-79.

19. Spangler W.I. and Kass P.H. (1999). Splenic myeloid metaplasia, histiocytosis and hypersplenism in the dog. Vet. Pathol. 36(6):583-593.

20. Udoh, P. and Kehinde A. (1999). Studies on antifertility effect of pawpaw seeds (Carica papaya) on the gonads of male albino rats. Phytother Res. 13:226-228. 